\title{
A Study on the Job Satisfaction of Tour Guides and its Influencing Factors
}

\author{
Chunyan Wang
}

\author{
College of Business Administration, Jilin Engineering Normal University, Changchun, China
}

541012329@qq.com

\section{Keywords: Tour guide; Job satisfaction; Influencing factor}

\begin{abstract}
Tour guide is the soul of the tourism that plays a pivotal role in the tourism industry. The job satisfaction of tour guide will directly affect the service quality of the tour guide. It has become an important issue to explore the factors that affect the job satisfaction the tour guide. This research makes online questionnaires to tour guides who work in Jilin province, and analyzes the results of 196 valid questionnaires, and found that some main problems of effecting the job satisfaction of tour guides, including hardly work intensity, less training opportunities, lack of labor contracts and social insurance and so on. Finally, it puts forward some suggestions such as establishing a reasonable salary system, a standardized training system and a strong guarantee mechanism for tour guides.
\end{abstract}

\section{Introduction}

As a mediator in tourism, tour guide is a bridge and link between the tourist destination, the travel agency and the tourists. Tour guide is an indispensable part of tourism activities, and plays an important role in tourism industry. The work attitude and behavior of tour guide directly affects the service quality of travel agency. Tour guide is the most important human capital, their job satisfaction is related to the quality and efficiency of their work, influences the satisfaction of tourists, and then impacts the reputation and image of travel agency. It can be seen that the job satisfaction of tour guides has a significant impact on tourists and travel agencies on tourism market.

The assessment of job satisfaction through employee anonymous surveys became commonplace in the 1930s. Hoppck (1935) conducted a study that focused explicitly on job satisfaction [1]. The main process factors of job satisfaction include management, promotion, work content, supervisors, treatment, working conditions, working partners, welfare, training and other aspects [2][3][4]. Rice and Gentile (1991) found that 12 important factors of job satisfaction: salary, working time, exchange of envoys, promotion opportunities, communication with colleagues, learning opportunities, decision-making right, material needs, spiritual needs, and time control [5]. According to Robbins (1998), five factors that determine job satisfaction, including work with psychological challenge, fair salary, supportive working environment, rapport with colleagues, and personality [6].

From the research results of the factors of job satisfaction, the research object formerly is mainly concentrated in the enterprise staff, nurses, hotel staff, teachers and other groups. There is little research on tour guides. In this study, the tour guide is taken as the object of study, and the influence factors of their job satisfaction are analyzed by questionnaire survey, and some suggestions are put forward according this analysis results.

\section{Variable Selection and Data Sources}

This study selected 10 variables as the factors affecting the job satisfaction of tour guide, including age, sex, marriage, education, certificate level, work experience, salary, work intensity, training times, labor contract and social insurance. Explanation and assignment of variables are shown in Table 1. The main object of this survey is tour guide who works in Jilin province. The survey data were collected through online questionnaires which were distributed to the tour guides in Changchun City, Jilin City, Tonghua City, Korean Autonomous Prefecture of Yanbian and other areas, and finally a total of 196 valid questionnaires were collected. 
Table 1 Variable interpretation

\begin{tabular}{|c|c|c|c|}
\hline Variable code & Name of variable & Value & Variable interpretation \\
\hline $\mathrm{Y}$ & $\begin{array}{l}\text { Job satisfaction } \\
\text { (dependent variable) }\end{array}$ & $1-5$ & $\begin{array}{l}\text { Very dissatisfied }=1, \text { Dissatisfied }=2, \\
\text { Normal }=3 \text {, Satisfied }=4 \text {, Very satisfied }=5\end{array}$ \\
\hline $\mathrm{X}_{1}$ & Sex & $0-1$ & Male $=0$, Female $=1$ \\
\hline $\mathrm{X}_{2}$ & Age & $1-4$ & $\begin{array}{l}\text { Under } 18 \text { years old }=1,18-25 \text { years old }=2,26-40 \\
\text { years old }=3, \text { Above } 40 \text { years old }=4\end{array}$ \\
\hline$X_{3}$ & Marriage & $0-1$ & Unmarried $=0$, Married $=1$ \\
\hline $\mathrm{X}_{4}$ & Education & $1-4$ & $\begin{array}{l}\text { High school }=1 \text {, Junior college }=2, \\
\text { Undergraduate }=3 \text {, Postgraduate and above }=4\end{array}$ \\
\hline $\mathrm{X}_{5}$ & Certificate level & $1-4$ & $\begin{array}{l}\text { Primary }=1, \text { Medium grade }=2, \text { Advanced }=3, \\
\text { Special grade }=4\end{array}$ \\
\hline$X_{6}$ & Work experience & $1-4$ & $\begin{array}{l}\text { Under } 2 \text { years }=1,2-5 \text { years }=2,6-10 \text { years }=3 \text {, } \\
\text { More than } 10 \text { years }=4\end{array}$ \\
\hline $\mathrm{X}_{7}$ & Salary & $1-4$ & $\begin{array}{l}\text { Below } 2000 \text { yuan }=1,2000-2500 \text { yuan }=2, \\
2501-3000 \text { yuan }=3 \text {, More than } 3000 \text { yuan }=4\end{array}$ \\
\hline $\mathrm{X}_{8}$ & Work intensity & $1-5$ & $\begin{array}{l}\text { Very tired }=1, \text { Tired }=2, \text { Normal }=3, \text { Easy }=4, \\
\text { Very easy }=5\end{array}$ \\
\hline $\mathrm{X}_{9}$ & Training frequency & $1-3$ & None $=1$, A few $=2, \quad$ Many $=3$ \\
\hline $\mathrm{X}_{10}$ & Labor contract & $0-1$ & $\mathrm{No}=0, \mathrm{Yes}=1$ \\
\hline $\mathrm{X}_{11}$ & Social insurance & $0-6$ & $\begin{array}{l}\text { None }=0, \text { one type }=1, \text { two types }=2, \text { three } \\
\text { types }=3 \text {, four types }=4, \text { five types }=5, \text { six types }=6\end{array}$ \\
\hline
\end{tabular}

\section{Descriptive Statistic of Questionnaire Results}

In the recovery of the 196 questionnaires, of which $4.79 \%$ of the tour guides for their work was "very satisfied" and $22.6 \%$ guides for their work is "satisfied", $55.48 \%$ of the guide's job satisfaction as a "normal", but there are still $15.75 \%$ of the tour guide feeling "dissatisfied", while with $1.37 \%$, tour guides feel "very dissatisfied". Thus, in this survey, most of the tour guides on their job satisfaction only feel "normal", at the same time, there are about $17 \%$ of the tour guides are "dissatisfied" or even "very dissatisfied" on their job. The descriptive statistical results of explanatory variables are shown in Table 2.

Table 2 Descriptive statistical results

\begin{tabular}{llllll}
\hline Variable & Sample number & Mean & Standard deviation & $\begin{array}{l}\text { Least } \\
\text { value }\end{array}$ & $\begin{array}{l}\text { Crest } \\
\text { value }\end{array}$ \\
\hline $\begin{array}{l}\text { Job satisfaction } \\
\text { (dependent variable) } \mathrm{Y}\end{array}$ & 196 & 3.137 & 0.785 & 1 & 5 \\
\hline Sex $\mathrm{X}_{1}$ & 196 & 0.719 & 0.451 & 0 & 1 \\
\hline Age $\mathrm{X}_{2}$ & 196 & 2.301 & 0.517 & 2 & 4 \\
\hline Marriage $\mathrm{X}_{3}$ & 196 & 0.760 & 0.428 & 0 & 1 \\
\hline Education $\mathrm{X}_{4}$ & 196 & 1.973 & 0.917 & 1 & 4 \\
\hline Certificate level $\mathrm{X}_{5}$ & 196 & 1.120 & 0.486 & 1 & 4 \\
\hline Work experience $\mathrm{X}_{6}$ & 196 & 1.753 & 0.921 & 1 & 4 \\
\hline Salary $\mathrm{X}_{7}$ & 196 & 2.795 & 1.089 & 1 & 4 \\
\hline Work intensity $\mathrm{X}_{8}$ & 196 & 2.473 & 0.807 & 1 & 5 \\
\hline Training frequency $\mathrm{X}_{9}$ & 196 & 1.260 & 0.440 & 1 & 2 \\
\hline Labor contract $\mathrm{X}_{10}$ & 196 & 0.247 & 0.443 & 0 & 1 \\
\hline Social insurance $\mathrm{X}_{11}$ & 196 & 0.548 & 1.329 & 1 & 6 \\
\hline
\end{tabular}


As can be seen from Table 2, the average value of tour guides' job satisfaction was 3.137 , on the whole, the job satisfaction of tour guides keeps the level of "normal", so there is still room for improvement. The average value of the variable of gender was 0.719 , that of female tour guides than male; the average value of age and marriage were 2.301 and 0.760 , that the guide is in the 18 to 25 years old married state; the average value of working experience was 1.753, that guides staff for two years. From the age and working experience of the tour guides were investigated, you can know that the tour guides are generally younger, have a short career time and seriously turnover tendency. The average level of education and certificate level of tour guide were 1.937 and 1.120. It can be seen that the most of tour guides are the primary tour guide who graduates from junior colleges, indicating that the tour guide diploma is lower, and the education level of tour guides to be upgraded. The average value of wages and work intensity were 2.795 and 2.473 , that tour guide work is hard work, but their wages are relatively low, generally from 2500 to 3000 yuan; the average value of training frequency was 1.260 times, that most of tour guides almost did not participate in training; the average value of the labor contract and social insurances were 0.247 and 0.548 , indicating that the tour guides almost did not sign labor contracts with travel agencies, and travel agencies did not buy social insurances for their tour guides.

\section{Problems Analysis}

Based on the results analysis in Table 2, it is concluded that there are still some problems in management of tour guides in Jilin province.

Work Intensity Greatly, not Proportional to Wages. According to the results of the survey, the work intensity of tour guides is greater, but their wages are low. The work content of tour guide is very trivial, including receiving tourists, making tour speech, explaining, maintaining security, dealing with the matters, etc.. So the work intensity of them is very great, especially in the peak season. However, most of the tour guides are "three noes", that is, no basic salary, no basic welfare protection, no clear labor remuneration. Most of the tour guides have low salary, while the rebate is their main source of income. Only a small number of full-time tour guides have a basic salary and with a group allowance, it is clear that their income and pay is not proportional. In this situation, tour guides have to through informal channels to obtain payment for labor. Many tour guides put most of their energies on the scenic spots and shopping at tourists' own expense, that eventually will make the tour guides do not feel satisfied with their works. This unreasonable salary system makes a lot of tour guides to face a crisis of survival, works seriously dampened the enthusiasm of them, even causes the tendency of turnover, is not conducive to long-term development of travel agencies and tourism market.

Less Training Opportunities. From the survey results, the majority of tour guides have not been trained. Prior to the practice, the tour guides did not receive a basic professional training, and the opportunities to learn less. Coupled with the backward of training concepts in the majority of travel agencies, but the economic benefits as the primary principle, the travel agencies settle on the short-term benefits. The training is regarded as a kind of no return, which is a waste of financial resources, material resources and manpower. At present, the only systematic training of tour guides is the annual training from China National Tourism Administration, but this training for a short time can not meet the needs of the skills and knowledge of the tour guides. When the knowledge and skills needed by the tour guides are not met, it is difficult to improve the salary and position, which will affect their job satisfaction.

Lack of Labor Contracts, Social Security and Other Insurances. From Table 2 shows that the travel agency almost did not sign labor contracts with tour guides, the social insurances of tour guides is on the edge of social security. Tour guides did not enjoy some social insurances from their companies, such as the endowment insurance, medical insurance, employment injury insurance, maternity insurance, unemployed insurance, housing fund, etc.. On the one hand, such a bad situation is caused by the travel agency to save labor costs, on the other hand is the lack of relevant provisions on the protection of tour guides' welfare. No security makes the tour guides lack of a sense of belonging, the tour guide is not only faced with tremendous economic pressure, but also with producing the occupation burnout, so many talented people withdraw from the tourism industry, that causes the lack of talents [7]. 


\section{Suggestions to Improve the Job Satisfaction of Tour Guides}

Through the above analysis, in order to improve the job satisfaction and work enthusiasm of the tour guides, realize their own value, and promote the development of the tourism industry, the following suggestions are put forward:

Establish a Reasonable System of Salary to Improve the Enthusiasm of Tour Guides. It is urgent to improve the job satisfaction of the tour guides and establish a reasonable salary system. The salary structure of the tour guides should be divided into three parts: basic salary, benefit compensation and employee benefits. The basic salary may be different from the tour guide's working experience and grade. On the one hand, that can retain the tour guides, reduce their turnover rate and increase their loyalty. On the other hand, it can reflect the fairness and efficiency of the compensation system. The benefit compensation should be different according to the quantity and quality of the tour groups led by the tour guides [8]. It will be helpful to improve the working enthusiasm of tour guides by combining the basic salary and benefit compensation of the tour guides. Employee benefits are defined as indirect compensation other than direct pay, including for the tour guides to solve the housing problems, the marital problems, the health problems, the child's education problems, etc.. This kind of salary system, while improving the job satisfaction of the tourist guide and protecting their basic interests, can stimulate the working enthusiasm of tour guides, retain the best potential of tour guides, and promote the development of tourism industry.

Establish a Standardized Training System to Improve the Level of Knowledge and Skills. Training is helpful to improve the competitiveness of tour guides, but also to meet the needs of the development of knowledge economy. The responsibilities and obligations of the standardized training system should be borne by the travel agencies and the service institutions of tour guides. They should take measures actively to encourage tour guides to participate in training. The service institutions of tour guides should cooperate with travel agencies, training establishments and other social institutions, to provide comprehensive training opportunities for tour guides, training content including service consciousness, occupation morals, laws and regulations, professional knowledge and so on. Travel agencies should also further strengthen the pre job training and on-the-job training for tour guides, to improve the quality of tour guides. These training should be arranged in the slack season, and follow the principle of voluntary and low-cost [9]. In short, the training work can not be dispensable, to gradually become part of the daily life of the tour guide, to form a mode of "working in the peak season, learning in the off-season".

Establish a Strong Guarantee Mechanism for Tour Guides to Protect Their Rights and Interests. A strong guarantee mechanism for tour guides needs the joint efforts of travel agencies, the relevant departments of the state, the labor department and so on. Travel agencies should be strictly in accordance with the "labor law", signed a labor contract with each tour guide, and to purchase the social insurances to protect the interests of tour guides. The relevant departments of the State shall carry out the necessary amendments to the existing "regulations on the management of tour guides", and specify clearly the personality, dignity and the rights and interests of the tour guides in the regulations. The labor department should take appropriate protection measures to tour guides in term of their employment, labor insurance, medical insurance, pension insurance and others, to ensure that the tour guide can get help from the tour guide service companies, travel agencies and government in cases of illness, maternity, injury, disability and retirement, in accordance with the law [10]. Through the joint efforts, the rights of tour guides are guaranteed, and their job satisfaction can be continuously improved, so as to provide excellent talents for the tourism industry, and to promote the long-term stable development of tourism.

\section{Acknowledgements}

This work was financially supported by Horizontal Scientific Research Project (Subject Title: The design of the salary scheme for tour guides in Kanghui International Travel Service, Tonghua Branch) and Jilin Engineering Normal University. 


\section{References}

[1] R. Hoppock: Job Satisfaction (Harper \& Brothers Publishers, England 1935), p.8-21.

[2] V.H. Vroom: Personnel Psychology, Vol. 15 (1962) No.2, p.159-177.

[3] P.C. Smith, L.M. Kendall and C.L. Hullin: The Measurement of Satisfaction in Work and Retirement: A Strategy for the Study of Attitudes (Rand and McNally, Chicago 1969), p.160-175.

[4] E.A. Locke: The Nature and Cause of Job Satisfaction (Rand McNally, Chicago 1976), p.1297-1349.

[5] R.W. Rice and D.A. Gentile: Journal of Applied Psychology, Vol. 76 (1991) No.1, p.31-39.

[6] S.P. Robbins: Organizational Behavior, Concept, Controversies, Applications (Prentice Hall, Upper Saddle River 1998)

[7] A.H. Zhao: Journal of Eastern Liaoning University (Social Sciences), Vol. 15 (2013) No.2, p.114-118.

[8] C.J. Zheng, X.L. Tong and P. Gong: Journal of Shijiazhuang University of Economics, Vol. 38 (2015) No.3, p.95-100.

[9] W. Wang: Tourism Overview, Vol. 9 (2012) No.9, p.45-46.

[10] W.J. Wang: A Study on the Link between Tour Guide Job's Satisfaction and Turnover Intention (MS., Shandong University, China 2010), p.41-42. 